\title{
Faktor Penyebab dan Cara Penyelesaian Konflik Antara Manajemen dan Serikat Pekerja
}

\author{
Sunarto \\ Jurusan Manajemen, Fakultas Ekonomi, Universitas Wahid Hasyim \\ Email : sunarto@unwahas.ac.id
}

\begin{abstract}
Abstrak
Penelitian ini bertujuan untuk menginvestigasi penyebab dan cara penyelesaian konflik antara manajemen dan serikat pekerja. Desain penelitian ini adalah studi kasus menggunakan pendekatan kualitatif dengan teknik pengumpulan data melakukan wawancara. Partisipan dalam penelitian ini sebanyak 4 orang unsur manajemen dan 6 orang unsur serikat pekerja di PT. Dok \& Perkapalan Kodja Bahari (Persero). Hasil penelitian menemukan faktor penyebab konflik : tertundanya pemenuhan hak normatif, komitmen sering tidak ditepati, dan kurang komunikasi yang harmonis antara manajemen dengan serikat pekerja. Pada penelitian ini juga menemukan cara penyelesaian konflik dengan membangun komunikasi efektif antara manajemen dan serikat pekerja melalui : komunikasi langsung, hubungan kekeluargaan dan berkesinambungan, kepercayaan dan komitmen serta keterbukaan informasi terhadap seluruh serikat pekerja yang ada.Penelitian ini memiliki implikasi praktis terhadap manajemen, sehingga serikat pekerja menyadari kondisi perusahaan, peran dan tanggung jawabnya sebagai mitra, membangun kepercayaan terhadap manajemen, yang pada akhirnya meminimkan terjadinya konflik.
\end{abstract}

Kata kunci : Penyebab konflik,Penyelesaian konflik, Manajemen dan serikat pekerja

\begin{abstract}
This research aims to analysis causes and ways of conflict resolution between management and worker's union. This research utilized qualitative case study approach the data were collected by interviews. Participants in this research involves 4 managers and 6 representatives from the worker union of PT. Dok \& Perkapalan Kodja Bahari (Persero). The research found that the antecedents of conflicts are : inability to fulfill the normative rights, lack of commitments from management and communication problem between management and the worker union. This research also found to that resorve conflict by establishing effective communication between management and the worker union through: direct communication, family - like relationships and continuous improvement, trust and commitment and openness information to all worker unions. This research has practical implications toward managerial practice. The worker unions must be aware of the condition of the company, its role and responsibilities as partners, building trust against management.
\end{abstract}

Keywords: Causes of conflicts, Conflict resolution, Management and Worker union

\section{PENDAHULUAN}

Ketika dua atau lebih individu, kelompok, organisasi, dan negara berhubungan satu sama lain dalam mencapai tujuannya mereka tidak sesuai atau tidak konsisten dan memiliki sikap, nilai, keyakinan dan ketrampilan yang berbeda, maka akan terjadi suatu konflik (Rahim 2017). Konflik dalam organisasi pada umumnya digeneralisasi oleh para peneliti merupakan perselisihan antara atasan dengan bawahan sehingga pentingnya kesesuaian antara atasan dan bawahan untuk menciptakan kondisi yang kondusif di lingkungan kerja yang lebih harmonis (Bélanger et al. 2015). Padahal dalam membangun dan membesarkan suatu perusahaan tidak hanya sebatas hubungan atasan dan bawahan saja, tetapi konflik antara manajemen dan serikat pekerja adalah fenomena umum yang perlu ditangani dengan cepat untuk meminimalkan konsekuensi merugikan terhadap iklim organisasi dan kinerja. Hal ini juga bisa meminimalisir terjadinya tindakan pemogokan ataupun hal lain yang bisa membuat banyak pihak mendapatkan kerugian. Penelitian ini menyadari sepenuhnya pentingnya kesesuaian antara atasan dan bawahan yang dikemukakan oleh Bélanger et al. (2015). Namun demikian,penelitian ini berpendapat paradoks terjadinya konflik merupakan perselisihan antara manajemen dan serikat pekerja. 
Dalam rangka mewujudkan hubungan industrial yang harmonis, dinamis, dan berkeadilan, pemerintah indonesia telah menetapkan undang-undang nomor 21 tahun 2000 tentang Serikat Pekerja/ Serikat Buruh. Memperhatikan Tambahan Lembaran Negara Republik Indonesia Nomor 3989 Penjelasan Undang-Undang Republik Indonesia Nomor 21 tahun 2000 tentang Serikat Pekerja/ Serikat buruh, bahwa "Pekerja/buruh merupakan mitra kerja pengusaha yang sangat penting dalam proses produksi dalam rangka meningkatkan kesejahteraan pekerja/buruh dan keluarganya, menjamin kelangsungan perusahaan, dan meningkatkan kesejahteraan masyarakat Indonesia pada umumnya."

Menurut Wakit Ketua Umum Kadin Indonesia Bidang Industri Johnny Darmawan bahwa kerugian akibat pemogokkan kerja menolak Omnibus Law Undang-undang Cipta Kerja selama 3 hari yang digelar secara nasional tidaklah sedikit . Ia mengungkapkan "Ada kerugian demandsupply karena stop produksi, stop pabrik juga. Ada yang sudah demand tapi tidak supply karena production problem. Itu kan bisa mengganggu kontrak. Dari segi anggka memang belum ada yang menghitung" (Indonesia 2020).

Situasi ini menunjukkan bahwa masing-masing pihak harus mengutamakan pendekatan kolaborasi dibandingkan dengan konflik didalam hubungan industrial. Dengan alasan pekerja/ buruh sebagai mitra kerja pengusaha dan terlihat masih banyak terjadinya pemogokan kerja, berarti mengabaikan fakta bahwa sampai saat ini masih banyak perselisihan antara manajemen dan serikat pekerja. Ini adalah tujuan penelitian untuk melakukan analisis faktor penyebab dan cara penyelesaian konflik antara manajemen dan serikat pekerja.

Untuk tujuan tersebut, PT. Dok \& Perkapalan Kodja Bahari (Persero) yang merupakan industri galangan kapal nasional dipilih sebagai studi kasus penelitian ini, karena karyawan perusahaan Badan Usaha Milik Negara (BUMN) tersebut pernah melakukan mogok kerja selama 1 (satu ) bulan mulai tanggal 10 Desember 2015 s/d 12 Januari 2016 dengan tuntutan pemenuhan hak normatif dan penolakan relokasi. Mogok kerja tersebut menimbulkan kerugian kepada perusahaan dan mendapat complain serta tuntutan dari pemilik kapal (pelanggan) yang tidak puas dengan kondisi tersebut. Bahkan beberapa pelanggan telah membatalkan rencana docking kapal mencapai lebih kurang Rp. 15 milyar dan akan terus bertambah jika kondisi tersebut tidak berubah. Mogok kerja tersebut semula direncanakan berlangsung selama 3(tiga) bulan mulai tanggal 10 Desember 2015 s/d 10 Maret 2016. Kemudian Menteri BUMN selaku pemegang saham perusahaan perseroan (Persero) PT. Dok \& Perkapalan Kodja Bahari telah mengambil langkah strategis dengan memberhentikan dan mengangkat jajaran manajemen PT. Dok \& Perkapalan Kodja Bahari (Persero). Selanjutnya dengan manajemen yang baru dilakukan komunikasi antara manajemen dan serikat pekerja dengan hasil kesepakatan mogok kerja dihentikan pada tanggal 13 Januari 2016.

Sulit untuk menjelaskan faktor penyebab dan cara penyelesaian konflik antara manajemen dan serikat pekerja, karena penelitian ini berbeda dengan penelitian terdahulu yang dilakukan oleh (Ayoko and Pekerti 2008), (Bélanger et al. 2015), (Femi 2014), (Lee Yook 2015), (Linke and Zerfass 2011), (Tanova and Nadiri 2010). Penelitian terdahulu cenderung mengeneralisasi terjadinya konflik karena perselisihan antara pimpinan dan bawahan. Penelitian ini berpendapatan paradoks terjadinya konflik karena perselisihan antara manajemen dan serikat pekerja. Metode penelitian terdahulu menggunakan pendekatan secara kuantitatif, sedangkan penelitian ini menggunakan pendekatan secara kualitatif, karena konflik hanya dapat dirasakan tetapi tidak bisa diukur secara obyektif. Penelitian ini pengumpulan datanya menggunakan wawancara dan narasumbernya hanya berjumlah 10 responden, sedangkan penelitian terdahulu memiliki banyak narasumber karena pengumpulan data yang dilakukan pada penelitian terdahulu menggunakan kuesioner sehingga sangat mungkin untuk bisa mencapai jumlah responden yang banyak. Teknik wawancara ini dipilih karena peneliti bisa berinteraksi langsung dengan narasumber yang terpercaya dan representative dalam memberikan informasi yang dibutuhkan. Pada teknik wawancara, ekpresi non verbal seperti ekspresi wajah dan gerakan tubuh dari responden dapat diketahui oleh peneliti sehingga data yang dikumpulkan menjadi lebih tepat (Mas'ud 2004). 


\section{METODE PENELITIAN \\ Jenis Penelitian}

Jenis penelitian yang digunakan adalah penelitian kualitatif, karena konflik hanya dapat dirasakan tetapi tidak bisa diukur secara obyektif. Penelitian ini dengan menggunakan pendekatan studi kasus. Desain studi kasus dalam penelitian ini menghadirkan situasi yang tidak biasa atau unik yang fokusnya pada kasus itu sendiri atau disebut kasus instrinsik, yaitu faktor penyebab dan cara penyelesaian konflik antara manajemen dan serikat pekerja pada PT. Dok \& Perkapalan Kodja Bahari (Persero).

\section{Sumber Data dan Teknik Pengumpulan Data}

Penelitian ini didasarkan menggunakan wawancara dengan unsur manajemen dan serikat pekerja di lingkungan PT. Dok \& Perkapalan Kodja Bahari (Persero) sebagai partisipan. Untuk pengumpulan data dalam penelitian ini dilakukan dengan wawancara. Tujuan penelitian ini adalah menginvestigasi hubungan antara manajemen dan serikat pekerja untuk menemukan faktor penyebab dan cara penyelesaian konflik pada PT. Dok \& Perkapalan Kodja bahari (Persero). Wawancara dilaksanakan secara semi terstruktur dan pada umumnya dilaksanakan selama lebih kurang 30 menit untuk masing-masing partisipan. Wawancara dilaksanakan dengan teknik probing yaitu pertanyaan didasarkan untuk mendorong partisipan berbicara dan mendiskusikan isu-isu tertentu yang berkaitan dengan topik penelitian ini, sehingga memperoleh pemahaman yang mendalam tentang faktor penyebab dan cara penyelesaian konflik antara manajemen dan serikat pekerja. Proses wawancara dilakukan dengan kerahasiaan dengan identitas dilindungi dengan nama-nama samaran. Proses dokumentasi wawancara dibuat menggunakan perekam suara ponsel. Dalam setiap wawancara, perangkat perekam diaktifkan dan file dari perangkat tersebut disalin ke komputer pribadi peneliti dan dikonversi ke dalam format MP3 sehingga file audio bisa diputar ketika dibuat transkrip wawancara dan menganalisis hasil wawancara.

\section{Partisipan}

Dalam rangka memperoleh informasi yang tepat sesuai fokus penelitian, maka strategi sampling primer yang digunakan dalam penelitian kualitatif ini adalah purposive sampling, yaitu peneliti memilih individu dan tempat untuk diteliti karena strategi ini memberikan secara spesifik pemahaman tentang permasalan riset dan fenomena sentral dalam studi tersebut. Sampling primer yang dipilih untuk menjadi partisipan pada penelitian ini, dengan kreteria sebagai berikut :

1. Unsur manajemen PT. Dok \& Perkapalan Kodja Bahari (Persero) yang membidangi sumber daya manusia.

2. Unsur serikat pekerja dilingkungan PT. Dok \& Perkapalan Kodja Bahari (Persero) yaitu serikat pekerja DKB GROUP, serikat pekerja SEKAR DKB GROUP dan serikat pekerja LEM SPSI .

Jumlah Partisipan dalam penelitian ini adalah 10 (sepuluh) responden yaitu 4 (empat) responden dari unsur manajemen dan 6 (enam) responden dari unsur serikat pekerja dengan alasan cukup representative, karena sudah melibatkan manajemen dan pengurus masing-masing serikat pekerja, sehingga diharapkan data yang diolah hasilnya bisa valid.

\section{Tahap Analisa Data}

Teknik analisis data yang digunakan dalam penelitian ini adalah analisis data kualitatif, mengikuti konsep yang diberikan Miles and Huberman, yaitu aktivitas dalam analisis data kualitatif dilakukan secara interaktif dan berlangsung secara terus menerus pada setiap tahapan penelitian sehingga tuntas, dan datanya sampai jenuh meliputi :

1. Data Reduction yaitu mengurangi data-data yang dianggap tidak penting. Pada tahapan ini data-data yang telah dipunyai oleh peneliti akan diteliti secara rinci dan detail serta hanya akan dicari data-data yang pokok, penting, dan yang berkaitan dengan tema penelitian.

2. Data Display yaitu penyajian data pada penelitian kualitatif ini dengan dengan menjelaskannya dalam uraian dan hubungan antar kategori.

3. Conclusions drawing/ verification yaitu kesimpulan yang diambil bersifat masih sementara. Dengan adanya bukti-bukti pendukung yang terpercaya dan valid, maka kesimpulan awal dapat diterima, dan kesimpulan tersebut dapat dikatakan relevan, oleh 
karena itu penting untuk verifikasi data yang telah diperoleh. Namun,apabila ditemukan fakta atau bukti yang lebih valid, dan itu berbeda dengan kesimpulan awal, maka akan diubah.

\section{Pengujian Kredibilitas Data}

Peneliti menggunakan teknik member check untuk validasi data tersebut setelah peneliti memasukkan data hasil wawancara yang telah dilakukan, yaitu proses pengecekan data oleh peneliti kepada narasumber. Teknik member check bertujuan untuk mengetahui seberapa jauh data yang diperoleh relevan dengan yang diberikan oleh narasumber, sehingga adanya kesamaan data yang dituliskan dengan data yang diperoleh dari narasumber.

\section{HASIL DAN PEMBAHASAN \\ Deskripsi Partisipan}

Jumlah narasumber sebanyak 10 (sepuluh) partisipan mencakup 8 (delapan) partisipan berjenis kelamin laki-laki dan 2 (dua) partisipan berjenis kelamin perempuan. Narasumber terdiri dari 4 (empat) partisipan merupakan unsur manajemen setingkat level I dan II yang membidangi SDM dan mengetahui kebijakan-kebijakan manajemen, serta 6 (enam) partisipan dari unsur serikat pekerja merupakan pengurus dari masing masing organisasi serikat pekerja yang menentukan arah dan tujuan organisasi tersebut. Untuk menjamin kerahasiaan identitas partisipan, maka partisipan dilindungi dengan nama-nama samaran termasuk nama organisasi serikat pekerjanya.

Tabel 1. Rincian Partisipan

\begin{tabular}{|c|l|l|l|l|l|}
\hline No. & $\begin{array}{c}\text { Nama } \\
\text { (samaran) }\end{array}$ & $\begin{array}{c}\text { Nama Organisasi } \\
\text { (samaran) }\end{array}$ & $\begin{array}{c}\text { Usia } \\
\text { (tahun) }\end{array}$ & Masa Kerja & Pendidikan \\
\hline 1. & Tatang & Manajemen & 47 & 13 & S1 \\
\hline 2. & Igor & Manajemen & 54 & 26 & S1 \\
\hline 3. & Buya & Manajemen & 52 & 27 & D3 \\
\hline 4. & Tina & Manajemen & 37 & 16 & S1 \\
\hline 5. & Tiwi & SP Rumput Laut & 48 & 26 & S1 \\
\hline 6. & Eko & SP Rumput Laut & 48 & 26 & SLTA \\
\hline 7. & Iwan & SP Mutiara & 49 & 28 & SLTA \\
\hline 8. & Agung & SP Mutiara & 48 & 26 & SLTA \\
\hline 9. & Yudo & SP Kerang & 50 & 26 & S2 \\
\hline 10. & Agus & SP Kerang & 50 & 27 & S1 \\
\hline
\end{tabular}

Kategori partisipan usia 51 tahun keatas sebanyak 20 persen dengan pendidikan S1 dan D3, Usia 40-50 tahun sebanyak 70 persen dengan pendidikan bervariasi yaitu SLTA, S1 dan S2, serta usia di bawah 40 tahun sebanyak 10 persen dengan pendidikan S1. Berdasarkan usia dan masa kerja, adanya kecenderungan usia tua mempunyai masa kerja lebih lama dibandingkan dengan usia muda. Usia diatas 50 tahun mempunyai masa kerja rata-rata 26,5 tahun dan usia 40-50 tahun mempunyai masa kerja rata-rata 24,5 tahun, serta usia dibawah 40 tahun mempunyai masa kerja rata-rata 16 tahun.Usia, masa kerja dan pendidikan dari partisipan bukan aspek yang penting untuk dipertimbangkan dalam penelitian ini, namun hanya untuk memperjelas identitas partisipan.

\section{Keabsahan Data}

Bukti atau data untuk penelitian studi kasus ini berasal dari sumber wawancara, yaitu 2 partisipan dari masing-masing organisasi serikat pekerja dan 4 partisipan dari unsur manajemen. Partisipan telah menyampaikan fakta-fakta dan opini penyebab konflik serta cara penyelesaian konflik antara manajemen dan serikat pekerja. Data yang terkumpul atas jawaban dari pertanyaanpertanyaan yang ditujukan kepada partisipan dalam organisasi yang sama telah menyatu serangkaian fakta atau temuan yang sama. Didalam Penelitian ini untuk menguji keabsahan data digunakan teknik membercheck, yaitu proses pengecekan data oleh peneliti kepada narasumber dengan tujuan untuk mengetahui relevansi dari narasumber sehingga ada kesamaan data. 


\section{Hasil Penelitian}

Pada tabel 2 para partisipan berpendapat penyebab konflik antara lain tertundanya pemenuhan hak normatif, komitmen manajemen sering tidak ditepati dan kurang terjalinnya komunikasi antara manajemen dengan serikat pekerja. Secara umum serikat pekerja dan manajemen menjelaskan faktor-faktor yang melatar belakangi penyebab terjadinya konflik dengan versi yang berbeda. Hal ini terlihat untuk mengamankan dan melindungi hak masing-masing yang dianggap sebagai kepentingannya. Ungkapan pemahaman yang berbeda dari versi serikat pekerja dan manajemen akan rawan timbulnya konflik dan timbul perasaan sensitive serta semakin memperlihatkan oposisi yang didorong rasa kecewa.

Tabel 2. Latar Belakang Penyebab Konflik antara Serikat Pekerja dan Manajemen

\begin{tabular}{|l|l|l|}
\hline Penyebab & $\begin{array}{l}\text { Latar Belakang } \\
\text { (versi serikat pekerja) }\end{array}$ & $\begin{array}{l}\text { Latar Belakang } \\
\text { (versi manajemen) }\end{array}$ \\
\hline $\begin{array}{l}\text { Tertundanya pemenuhan } \\
\text { hak normative }\end{array}$ & $\begin{array}{l}\text { Manajemen tidak memberi } \\
\text { solusi akibat kondisi } \\
\text { perusahaan sehingga } \\
\text { mengabaikan hak normatif }\end{array}$ & $\begin{array}{l}\text { Situasi dan kondisi } \\
\text { perusahaan yang belum } \\
\text { membaik }\end{array}$ \\
\hline $\begin{array}{l}\text { Komitmen manajemen } \\
\text { sering tidak ditepati }\end{array}$ & $\begin{array}{l}\text { Tidak ada niat baik dari } \\
\text { manajemen sehingga dead } \\
\text { lock dalam perundingan }\end{array}$ & $\begin{array}{l}\text { Kesulitan menjalankan } \\
\text { komitmen karena kondisi } \\
\text { perusahaan sehingga yang } \\
\text { direalisasikan sesuai } \\
\text { pendapatan }\end{array}$ \\
\hline $\begin{array}{l}\text { Kurang komunikasi antara } \\
\text { manajemen dan serikat } \\
\text { pekerja }\end{array}$ & $\begin{array}{l}\text { Adanya perbedaan } \\
\text { komunikasi yang dirasakan } \\
\text { oleh masing-masing serikat } \\
\text { perkerja dan cenderung } \\
\text { adanya kalaterisasi terhadap } \\
\text { organisasi serikat pekerja } \\
\text { yang anggotanya mayoritas } \\
\text { dan minoritas }\end{array}$ & $\begin{array}{l}\text { Adanya perbedaan } \\
\text { kepentingan antara } \\
\text { manajemen dan serikat } \\
\text { pekerja, karena serikat } \\
\text { pekerja cenderung lebih } \\
\text { dominan dengan tuntutan }\end{array}$ \\
\hline
\end{tabular}

Tabel 3. Persepsi Masing-masing Serikat Pekerja terhadap Manajemen Berhubungan dengan Konflik

\begin{tabular}{|l|l|l|l|}
\hline $\begin{array}{l}\text { Nama } \\
\text { serikat } \\
\text { pekerja }\end{array}$ & $\begin{array}{l}\text { Reaksi akan } \\
\text { tertundanya hak } \\
\text { normatif }\end{array}$ & $\begin{array}{l}\text { Persepsi terhadap } \\
\text { komitmen manajemen }\end{array}$ & $\begin{array}{l}\text { Persepsi terhadap } \\
\text { komunikasi antara } \\
\text { manajemen dengan } \\
\text { serikat pekerja }\end{array}$ \\
\hline $\begin{array}{l}\text { SP } \\
\text { Rumput } \\
\text { Laut }\end{array}$ & $\begin{array}{l}\text { Mendukung mogok } \\
\text { kerja }\end{array}$ & $\begin{array}{l}\text { Manajemen sekarang } \\
\text { lebih berkomitmen dan } \\
\text { bertanggung jawab } \\
\text { dibandingkan } \\
\text { manajemen lama }\end{array}$ & $\begin{array}{l}\text { Merasa sudah } \\
\text { memadai } \\
\text { dibandingkan } \\
\text { manajemen lama }\end{array}$ \\
\hline $\begin{array}{l}\text { SP } \\
\text { Mutiara }\end{array}$ & $\begin{array}{l}\text { Mendukung mogok } \\
\text { kerja }\end{array}$ & $\begin{array}{l}\text { Manajemen lama lebih } \\
\text { berkomitmen dan } \\
\text { bertanggung jawab } \\
\text { dibandingkan } \\
\text { manajemen sekarang }\end{array}$ & $\begin{array}{l}\text { Merasa belum } \\
\text { memadai } \\
\text { dibandingkan } \\
\text { manajemen lama }\end{array}$ \\
\hline $\begin{array}{l}\text { SP } \\
\text { Kerang }\end{array}$ & $\begin{array}{l}\text { Tidak mendukung } \\
\text { mogok kerja dan lebih } \\
\text { memilih membangun } \\
\text { komunikasi }\end{array}$ & $\begin{array}{l}\text { Manajemen lama lebih } \\
\text { berkomitmen dan } \\
\text { bertanggung jawab } \\
\text { dibandingkan } \\
\text { manajemen sekarang }\end{array}$ & $\begin{array}{l}\text { Merasa belum } \\
\text { memadai } \\
\text { dibandingkan } \\
\text { manajemen lama }\end{array}$ \\
\hline
\end{tabular}


Pada tabel 3 telah terungkap dengan tertundanya pemenuhan hak normatif karyawan, SP Rumput Laut dan SP Mutiara mendukung dan melakukan mogok kerja atau unjuk rasa. Hal ini tentunya merupakan alasan yang wajar, karena beraneka kebutuhan hidup karyawan yang semakin meningkat. Kebutuhan hidup karyawan yang tidak terpenuhi apabila berkelanjutan terus, tentunya dapat mengakibatkan efek-efek tidak produktif seperti berkurangnya semangat karyawan untuk melaksanakan aktifitas di perusahaan, semakin merenggangnya hubungan yang harmonis antara manajemen dan serikat pekerja serta kerugian perusahaan. Namun tidak semua serikat pekerja mendukung aksi mogok kerja walaupun tertundanya hak normatif, yaitu SP Kerang lebih memilih dengan cara membangun komunikasi. Hal ini merupakan sikap yang rasional juga, karena sebagai dampak dari mogok kerja tersebut bagi masing-masing pihak sangat merugikan, yaitu operasional perusahaan terhenti dan merugikan finansial yang ironisnya justru merugikan karyawan itu sendiri. Kerugian bagi manajemen dapat menurunkan daya saing perusahaan, sedangkan kerugian bagi karyawan tentunya dengan menurunnya kualitas daya saing perusahaan akan berdampak kepada besaran kekuatan finansial perusahaan dalam memberikan kesejahteraan karyawan.

Hal ini menguatkan hasil penelitian (Bélanger et al. 2015) mengamati bahwa"Dalam pengelolaan konflik cenderung lebih memilih strategi konstruktif (berorientasi solusi) dari pada kekuatan atau kekuasaan." Oleh karena itu, sebuah fenomena umum terjadinya konflik yang mengarah timbulnya pemogokan kerja,harus ditangani dengan cepat untuk meminimalkan berbagai kerugian. Namun, hak mogok adalah konsekuensi instrinsik untuk dilindungi ILO nomor 87, karena para pekerja PT. Dok \& Perkapalan Kodja Bahari (Persero) tersebut bukan layanan penting dan bukan pegawai negeri menggunakan wewenang atas nama negara. Sesuai ketentuan pasal 137 Undang-undang Nomor 13 tahun 2003 tentang Ketenagakerjaan, bahwa "Mogok kerja sebagai hak dasar pekerja/ buruh dan serikat pekerja/ serikat buruh dilakukan secara sah, tertib, dan damai sebagai akibat gagalnya perundingan."

Temuan berikutnya, penyebab konflik antara serikat pekerja dengan manajemen adalah komitmen manajemen terhadap serikat pekerja yang sering tidak ditepati. Kurangnya komitmen manajemen terhadap serikat pekerja ini, pada umumnya diungkapkan oleh semua serikat pekerja yang ada. Pendapat para serikat pekerja tersebut bisa dikatakan adanya perbedaan persepsi dan interpretasi dalam melihat sejauh mana komitmen dan tanggung jawab manajemen. SP Rumput Laut mengartikan bahwa manajemen baru lebih berkomitmen dan bertanggung jawab dibandingkan manajemen lama.Sebaliknya SP Mutiara dan SP Kerang mengartikan manajemen lama lebih berkomitmen dan bertanggung jawab dibandingkan manajemen baru. Mana yang lebih berkomitmen dan bertanggung jawab antara manajemen baru atau manajemen lama, bukan merupakan konteks dalam penelitian ini. Konstektual dalam penelitian ini adalah melihat makna pentingnya komitmen dan tanggung jawab manajemen terhadap serikat pekerja sehingga tidak menimbulkan konflik.

Sejalan dengan hasil penelitian ini, (Femi 2014) mengamati bahwa "Ada hubungan antara komunikasi yang efektif dengan kinerja, produktivitas dan komitmen." Oleh karena itu pentingnya manajemen menghilangkan hambatan komunikasi dan memberikan gambaran yang realistis tentang kondisi dan situasi perusahaan terhadap perikat kekerja dalam memberikan pendapat atau gagasan untuk memecahkan persoalan. Adanya keterlibatan atau umpan balik dari serikat pekerja dalam menyelesaikan masalah perusahaan akan memberi arti bahwa kesulitan dari manajemen dalam menjalankan komitmen yang telah dibuat dengan serikat pekerja, dapat dilihat sebagai proses tahapan-tahapan maksimal dari tanggung jawab yang dilakukan manajemen untuk menuju perusahaan yang lebih baik.

Hasil temuan selanjutnya terungkap bahwa penyebab konflik antara serikat pekerja dengan manajemen adalah kurang terjalinnya komunikasi yang harmonis antara manajemen dan serikat pekerja. Sesuai yang diungkapkan oleh beberapa partisipan, terlihat bahwa yang mendasari kurangnya komunikasi yang harmonis antara serikat pekerja dan manajemen adalah adanya perbedaan hubungan komunikasi manajemen yang dirasakan oleh masing-masing serikat pekerja. SP Rumput Laut berpendapat komunikasi yang dirasakan saat ini telah memadai, karena manajemen sekarang selalu menanggapi aspirasi dari serikat pekerja. SP Mutiara mengungkapkan komunikasi yang dirasakan belum memadai, karena manajemen sekarang kurang terbuka dibandingkan manajemen lama. SP Kerang menjelaskan komunikasi yang dirasakan belum 
memadai juga, karena manajemen sekarang seperti ada kasterisasi dalam berkumunikasi dengan serikat pekerja. Perbedaan persepsi dari masing-masing serikat pekerja akan berpotensi memunculkan konflik antara sesama pekerja yang dapat meresahkan dan menganggu ketenangan bekerja dan kenyamanan berproduksi yang bermuara terganggunya kinerja perusahaan. Lebih menggenaskan kalau para pekerja merasa terkotak-kotakan dan dikhawatirkan timbul konflik kepentingan.Untuk mereduksi kekhawatiran tersebut, perlunya membangun komunikasi yang harmonis antara manajemen dengan seluruh serikat pekerja yang ada diperusahaan, tanpa memandang sedikitpun dari masing-masing organisasi tersebut.

Sejalan dengan hasil penelitian ini, (Femi 2014) mengamati bahwa "komunikasi yang efektif antara manajemen dan pekerja dapat menciptakan saling pengertian dalam membangun hubungan yang tulus antara kedua belah pihak." Dengan demikian kemitraan atau sinergi strategis perlu diciptakan dengan semangat kerjasama agar terjalin komunikasi yang harmonis dan bermanfaat bagi manajemen maupun serikat pekerja.

Hasil penelitian ini para partisipan juga mengungkapkan cara penyelesaian untuk menghindari konflik antara manajemen dan serikat pekerja sebagaimana pada tabel 4 antara lain melalui komunikasi langsung, kekeluargaan dan berkesinambungan, komiten dan kepercayaan , dan keterbukaan informasi.

Tabel 4. Persepsi Masing-masing Serikat Pekerja Terhadap Manajemen dalam Menghindari Konflik

\begin{tabular}{|l|l|l|l|l|}
\hline $\begin{array}{l}\text { Nama } \\
\text { Serikat } \\
\text { Pekerja }\end{array}$ & $\begin{array}{l}\text { Komunikasi } \\
\text { langsung }\end{array}$ & $\begin{array}{l}\text { Kekeluargaan dan } \\
\text { berkesinambungan }\end{array}$ & $\begin{array}{l}\text { Komitmen dan } \\
\text { kepercayaan }\end{array}$ & $\begin{array}{l}\text { Keterbukaan } \\
\text { informasi }\end{array}$ \\
\hline $\begin{array}{l}\text { SP } \\
\text { Rumput } \\
\text { Laut }\end{array}$ & $\begin{array}{l}\text { Sering } \\
\text { dilakukan oleh } \\
\text { manajemen } \\
\text { sekarang }\end{array}$ & $\begin{array}{l}\text { Sudah terealisasi } \\
\text { oleh manajemen } \\
\text { sekarang }\end{array}$ & Puas & $\begin{array}{l}\text { Manajemen } \\
\text { sekarang mulai } \\
\text { terbuka }\end{array}$ \\
\hline $\begin{array}{l}\text { SP } \\
\text { Mutiara }\end{array}$ & $\begin{array}{l}\text { Minim sekali } \\
\text { dilakukan } \\
\text { dibandingkan } \\
\text { manajemen } \\
\text { lama }\end{array}$ & $\begin{array}{l}\text { Belum terealisasi } \\
\text { oleh manajemen } \\
\text { sekarang }\end{array}$ & Belum puas & $\begin{array}{l}\text { Ada hal-hal } \\
\text { tertentu yang } \\
\text { disembunyikan }\end{array}$ \\
\hline $\begin{array}{l}\text { SP } \\
\text { Kerang }\end{array}$ & $\begin{array}{l}\text { Minim sekali } \\
\text { dilakukan } \\
\text { dibandingkan } \\
\text { manajemen } \\
\text { lama }\end{array}$ & $\begin{array}{l}\text { Belum terealisasi } \\
\text { oleh manajemen } \\
\text { sekarang }\end{array}$ & Belum puas & Disembunyikan \\
\hline
\end{tabular}

Pada tabel 4 menjelaskan Realita komunikasi yang terjadi menurut para partisipan telah terungkap berbeda beda. SP Rumput Laut mengakui komunikasi langsung telah berlangsung pada era manajemen sekarang, dengan alasan setiap ada permasalahan bisa bertemu langsung dengan manajemen. SP Mutiara dan SP Kerang mengungkapkan komunikasi langsung yang dirasakan saat ini masih minim sekali dibandingkan pada era manajemen sebelumnya, dengan alasan adanya gap dan cenderung adanya penundaan audiensi ketika serikat pekerja mengusulkan untuk bertemu dengan manajemen.

Hasil penelitian ini, mendukung peran konteks budaya dalam komunikasi langsung oleh Tanova and Nadiri (2010) menunjukkan "keberadaan serikat pekerja dan peran strategis HRM semua memiliki pengaruh pada komunikasi langsung." Oleh karena itu , ketika berbagi informasi melalui komunikasi langsung, serikat pekerja akan merasa mendapatkan informasi yang sebenarbenarnya tentang kondisi perusahaan dan mereka akan lebih bersedia untuk menyumbangkan ideide atau pemikirannya yang berguna bagi perusahaan., serta menyadari masalah kesulitan yang dihadapi oleh manajemen terutama dalam pemenuhan hak-hak normatif karyawan.

Dengan komunikasi secara langsung, ekspresi wajah dan gesture tubuh akan menunjukkan keadaan yang sebenarnya dan para pihak akan mudah menangkap untuk mempersepsikannya. Selain itu juga dapat menimbulkan sentuhan hati maupun sentuhan manusiawi untuk saling 
memahami dan merasakan atas permasalahan dari masing-masing pihak yang pada akhirnya terjalin komunikasi yang baik dan meminimkan terjadinya konflik.

Selanjutnya untuk meminimkan konflik dari penelitian ini adalah hubungan kekeluargaan dan berkesinambungan. Keinginan partisipan yang mengungkapkan pentingnya hubungan yang bersifat kekeluargaan dan berkesinambungan ini perlu ditanggapi secara positif oleh manajemen agar sekaligus merupakan pengakuan dan penghargaan bagi serikat pekerja telah peduli terhadap nasib perusahaan. Menurut pengakuan SP Kerang, komunikasi yang bersifat kekeluargaan ini telah terjalin pada manajemen lama, namun sifat kekeluargaan ini belum dirasakan pada manajemen sekarang. Pengakuan yang sama juga diungkapkan oleh SP Mutiara. Akan tetapi sesuai pengakuan SP Rumput Laut untuk komunikasi terus menerus ini telah dilakukan oleh manajemen sekarang dengan memberikan informasi yang sebenar-benarnya tentang kondisi perusahaan.

Atas perbedaan pendapat dari masing masing serikat pekerja tersebut, menunjukkan betapa keinginannya dari serikat pekerja bahwa komunikasi yang bersifat kekeluargaan ini dapat direalisasikan. Pentingnya komunikasi kekeluargaan karena memiliki nilai positif disamping adanya kertelibatan atau partisipasi dari serikat pekerja terhadap nasib perusahaan, manajemen juga dapat mengetahui masalahnya secara dini, dan dapat mencegah dan mengambil langkah penyelesaian agar masalah-masalah yang ada tidak menjadi lebih besar. Ini tentunya sangat berguna untuk bisa menciptakan terjalinnya komunikasiyang harmonis dalam suasana yang kondusif dan tidak terpicu adanya permasalahan yang mendorong terjadinya konflik yang berujung pada mogok kerja. Dengan membangun hubungan kekeluargaan dan berkesinambungan, manajemen dan serikat pekerja akan lebih menyadari peran dan tanggung jawabnya sebagai mitra dan bukan menggalang kekuatan untuk memusuhi manajemen, serta manajemen tidak hanya ingin menekan serikat pekerja, tetapi bersama serikat pekerja berusaha bekerjasama untuk mencapai tujuan bersama, yaitu kelangsungan hidup dan kemajuan perusahaan.

Selanjutnya dalam penelitian ini, untuk menghindari konflik antara manajemen dan serikat pekerja yaitu kepercayaan dan komitmen. Hasil penelitian ini, terungkap komitmen dan kepercayaan dapat dibangun melalui kepuasan serikat pekerja, jika manajemen melaksanakan apa yang sudah tertuang dalam perjanjian kerja bersama. Sesuai Undang-undang No. 21 tahun 2000 Bab VI pasal 25 point (a) bahwa "Serikat pekerja/ serikat buruh, federasi dan konfederasi serikat pekerja/ serikat buruh yang telah mempunyai nomor bukti pencatatan berhak: membuat perjanjian kerja bersama dengan pengusaha." Oleh karena itu,ungkapan partisipan ini merupakan hal yang rasional, karena keberadaan perjanjian kerja bersama sebagai salah satu sarana utama dalam pelaksanaan hubungan industrial, sampai sekarang masih dipertahankan dan bahkan terus dikembangkan dan dimasyarakatkan pelaksanaannya dalam masyarakat industrial di Indonesia. Selama jangka waktu berlakunya perjanjian kerja bersama masing-masing pihak terikat oleh kesepakatan sehingga manajemen dan pekerja (serikat pekerja) mempunyai kepastian dalam hakhak dan kewajiban.

Komitmen dan kepercayaan dalam penelitian ini, juga terungkap dapat dibangun melalui saling percaya antara manajemen dan serikat pekerja. Hal ini terlihat ungkapan kekhawatiran partisipan terhadap serikat pekerja lain yang tidak proaktif untuk mengetahui kondisi perusahaan yang sebenarnya, dan adanya blanksport serikat pekerja lain yang merasa tidak dikomunikasikan, serta ungkapan manajemen merasa umpan balik dari serikat pekerja kurang signifikan. Namun demikian SP Rumput Laut mengakui manajemen sekarang sudah mulai terbuka dan menyampaikan hasil kinerjanya walaupun tidak secara resmi. Namun menurut pengakuan serikat pekerja yang lain merasa hal tersebut tidak pernah dikomunikasikan sehingga bisa dikatakan belum puas.

Dengan demikian masing-masing pihak harus saling percaya antara satu sama lain, maka organisasi tersebut bisa kuat, kompak dan dapat bekerjasama. Tanpa kepercayaan akan muncul kecurigaan. Kelompok yang curiga kepada kelompok lain dikhawatirkan tidak akan mau bekerjasama, dan akan selalu mencari cara menghindari interaksi atau hubungan dengan kelompok yang dicurigai. Oleh sebab itu, manajemen harus mulai berpikir betapa pentingnya umpan balik, apakah itu signifikan atau tidak, tetapi dengan merespon untuk melibatkan seluruh serikat pekerja yang ada akan membangun kepercayaan pada manajemen. Hal ini menunjukkan manajemen telah peduli dan memperhatikan keberadaan serikat pekerja. Dengan alasan tersebut, serikat pekerja 
dapat melihat komitmen manajemen dan membangun kepercayaan mereka yang pada akhirnya akan meminimkan timbulnya konflik.

Disamping beberpa hal tersebut diatas, dalam meminimkan konflik antara manajemen dan serikat pekerja yaitu keterbukaan informasi. Ungkapan para partisipan ini merupakan hal yang wajar pada era reformasi yang mengarah semakin meningkatnya kesadaran akan keterbukaan informasi yang harus dilakukan manajemen dalam mengambil setiap kebijakan. Dalam membangun keterbukaan informasi antara manajemen dan serikat pekerja pada penelitian ini, memperkuat temuan sebelumnya (Ayoko and Pekerti 2008) "Telah memberikan kontribusi terhadap pengembangan lebih lanjut dari konstruksi kepercayaan tempat kerja, konflik dan keterbukaan komunikasi." Secara khusus mereka memgidentifikasi bahwa konflik dan keterbukaan komunikasi memiliki hubungan yang positif dengan kepercayaan. Oleh sebab itu, melalui keterbukaan informasi ini akan semakin dapat diterima oleh serikat pekerja dalam menjalin hubungan harmonis dengan manajemen.

Hal ini diharapkan dapat memberikan dampak perubahan yang sangat besar dan mendasar bagi hubungan antara manajemen dan serikat pekerja, mengingat hasil penelitian ini terungkap partisipan SP Kerang merasakan ada sesuatu dari manajemen yang disembunyikan, SP Mutiara merasakan ada hal-hal tertentu yang belum disosialisasikan, dan SP Rumput Laut merasakan manajemen baru justru mulai terbuka dibandingkan manajemen lama. Ungkapan pemahaman yang berbeda dari masing-masing serikat pekerja ini akan rawan timbulnya konflik dan timbul perasaan yang sensitif serta semakin memperlihatkan oposisi yang didorong rasa kecewa, karena dengan sikap yang berbeda antara kelompok satu dengan kelompok lainnya. Hal ini akan membangkitkan permusuhan, sikap apatis dan ketidak kepercayaan, terutama mereka yang dianggap antagonis dan kelompok serikat pekerja yang merasa tidak puas. Untuk mengantisipasi persoalan ini dan dalam mempertahankan hubungan yang harmonis, manajemen dapat melakukan dengan berbagai cara untuk memahami pola berpikir mereka melalui keterbukaan informasi kepada seluruh serikat pekerja tanpa memandang sebelah mata baik itu mayoritas atau minoritas, sehingga dapat menghambat persepsi negatif dan merasa kelompok organisasinya menjadi bermakna, serta dipandang memperlakukan yang sama terhadap seluruh serikat pekerja yang ada di perusahaan secara adil dan obyektif.

Hasil penelitian ini juga terungkap pemahaman yang berbeda dari kelompok serikat pekerja yang yang satu dengan kelompok serikat pekerja lainnya. Hal ini menunjukkan bahwa kelompok serikat pekerja yang puas untuk mempertahankan hubungan yang baik dengan cara memahami pola berpikir manajemen, dan bagi kelompok serikat pekerja yang tidak puas cenderung mempunyai persepsi dan interprestasi yang negatif. Hasil temuan ini mendukung teori identitas sosial dari Tajfel (Berger, 2016) "Mendistorsi persepsi in-group dan out-grup, atau langsung menyerang out-group demi mempertahankan keuntungan."

\section{KESIMPULAN DAN SARAN}

Berdasarkan hasil analisa data hasil wawancara dari responden ditemukan penyebab konflik antara manajemen dan serikat pekerja di PT. Dok \& Perkapalan Kodja Bahari (Persero) antara lain : tertundanya pemenuhan hak normatif, komitmen manajemen sering tidak ditepati, dan kurang terjalinnya komunikasi yang harmonis antara manajemen dengan serikat pekerja. Pada penelitian ini ditemukan pula cara penyelesaian atau menghindari konflik antara manajemen dan serikat pekerja antara lain : komunikasi langsung, hubungan kekeluargaan dan berkesinambungan, kepercayaan dan komitmen, serta keterbukaan informasi terhadap seluruh serikat pekerja yang ada. Penelitian ini mendukung teori identitas sosial dari Tajfel (Berger, 2016) "Mendistorsi persepsi in-group dan out-grup, atau langsung menyerang out-group demi mempertahankan keuntungan."

Temuan ini penting karena mempunyai alasan, bahwa penelitian ini memiliki implikasi praktis yang mendasar bagi manajemen dalam menjalin keharmonisan antara manajemen dan serikat pekerja, sehingga menjadikan serikat pekerja menyadari masalah kesulitan yang dihadapi oleh manajemen terutama dalam pemenuhan hak-hak normatif karyawan. Serikat pekerja akan lebih menyadari peran dan tanggung jawabnya sebagai mitra dan bukan menggalang kekuatan untuk memusuhi manajemen. Serikat pekerja dapat melihat komitmen manajemen dan membangun kepercayaan mereka yang pada akhirnya akan meminimkan timbulnya konflik. Serikat pekerja dapat menghambat persepsi negatif terhadap manajemen, dan serikat pekerja akan memandang 
manajemen memperlakukan yang sama terhadap seluruh serikat pekerja yang ada di perusahaan secara adil dan obyektif.

Penelitian ini memiliki keterbatasan respondennya sangat spesifik hanya satu perusahaan BUMN yang pemegang sahamnya sebagian besar milik pemerintah dan tidak membandingkan dengan perusahaan swasta yang pemegang sahamnya sebagian besar adalah manajemen itu sendiri. Pada penelitian selanjutnya atau penelitian masa depan disarankan menyelidiki penyebab dan cara penyelesaian konflik antara manajemen dan serikat pekerja dengan membandingkan perusahaan BUMN dan swasta. Dengan terungkap adanya dukungan teori identitas sosial dari Tajfel (Berger, 2016), maka pada penelitian selanjutnya disarankan pula untuk menyelidiki faktor-faktor pendorong dan dampak adanya in-group dan out-grup terhadap organisasi serikat pekerja maupun perusahaan.

\section{DAFTAR PUSTAKA}

Ayoko, Oluremi B., and Andre A. Pekerti. 2008. "The Mediating and Moderating Effects of Conflict and Communication Openness on Workplace Trust." International Journal of Conflict Management 19(4): 297-318.

Bélanger, Jocelyn J. et al. 2015. "Handling Conflict at Work: The Role of Fit between Subordinates' Need for Closure and Supervisors' Power Tactics.” International Journal of Conflict Management 26(1): 25-43.

Femi, ASAMU Festus. 2014. "The Impact of Communication on Workers' Performance in Selected Organisations in Lagos State, Nigeria." IOSR Journal of Humanities and Social Science 19(8): 75-82.

Indonesia, CBNC. 2020. “Omnibus Law Cipta Kerja."

John W. Creswell. 2015. Penelitian Kualitatitif \& Desain Riset. 3rd ed. ed. SaifuddinZuhry Qudsy. Yogyakarta: Pustaka Pelajar.

Lee Yook, Eunkyong. 2015. "An Exploratory Cross-Cultural Analysis of Communication Apprehension Between French and American Managerial and Non-Managerial Employees." Global Business \& Management Research 7(4): 1-7.

Linke, Anne, and Ansgar Zerfass. 2011. "Internal Communication and Innovation Culture: Developing a Change Framework." Journal of Communication Management 15(4): 332 48.

Mas'ud, Fuad. 2004. Survai Diagnosis Organisasional. 1st ed. Semarang: Universitas Diponegoro.

Rahim, M. Afzalur. 2017. "Managing Conflict in Organizations."

Sekaran. 2015. Research Methods for Business. 1st ed. Jakarta: Salemba Empat.

Sugiyono. 2014. Memahami Penelitian Kualitatif. Bandung: Alfa Beta.

Tanova, Cem, and Halil Nadiri. 2010. "The Role of Cultural Context in Direct Communication." Baltic Journal of Management 5(2): 185-96. 